\title{
ANALYSIS OF SCIENCE PROCESS SKILLS IN HANDS ON ACTIVITY IN APPLICATION OF THE PODE MODEL IN ELEMENTARY SCHOOL
}

Fiky Herdianto, Hartono Hartono, Ali Sunarso

Postgraduate Semarang State University, Semarang, Indonesia

E-mail: fikyherdianto@students.unnes.ac.id, hartono@mail.unnes.ac.id , alisunarso@mail.unnes.ac.id

\begin{tabular}{|c|c|}
\hline ARTICLE INFO & ABSTRACT \\
\hline $\begin{array}{l}\text { Received: } \\
\text { November, } 26^{\text {th }} \\
2021 \\
\text { Revised: } \\
\text { December, } 17^{\text {th }} \\
2021 \\
\text { Approved: } \\
\text { December, 19th } \\
2021\end{array}$ & $\begin{array}{l}\text { The low learning outcomes of science in grade IV elementary } \\
\text { school. The learning process still uses conventional methods } \\
\text { which can cause students to be less directly involved in direct } \\
\text { practical activities and active discussion during learning. It is } \\
\text { necessary to apply the Hands On Activity approach in the } \\
\text { application of the PODE model to improve students' science } \\
\text { process skills. The purpose of this study was to analyze the } \\
\text { science process skills in Hands On Activity in the application of } \\
\text { the PODE learning model in elementary schools. This type of } \\
\text { research is a Quasi Experimental Design in the form of } \\
\text { Nonequivalent Control Group Design. The sample in this study } \\
\text { amounted to } 60 \text { fourth grade students. Data collection } \\
\text { techniques using observation sheets, indicators of science } \\
\text { process skills consist of observing, classifying, experimenting, } \\
\text { communicating and concluding. Data analysis used simple and } \\
\text { multiple linear regression test. The results showed that the } \\
\text { science process skills of the experimental class applying Hands } \\
\text { on Activity and the PODE model were } 76.4 \% \text { and } 61.2 \% \text {, while } \\
\text { the PODE model control class had an effect of } 50.7 \% \text {. The } \\
\text { results of multiple linear tests obtained results of } 76.5 \% \text {, the } \\
\text { results of Sig. Simultaneous effect test is } 0.000<0.05 \text { and } \\
\text { Fcount } 43.897>\text { Ftable 3.33, and it can be concluded that there } \\
\text { is an effect of Hands on Activity (X1) and PODE model (X2) } \\
\text { simultaneously on science process skills. }\end{array}$ \\
\hline
\end{tabular}

Fiky Herdianto, Hartono Hartono, Ali Sunarso (2021). Analysis of Science Process Skills in Hands on Activity in Application of the Pode Model In Elementary School. Journal Eduvest. 1(12): 14051417

How to cite:

E-ISSN:

Published by: 
Fiky Herdianto, Hartono Hartono, Ali Sunarso

\begin{tabular}{ll}
\hline KEYWORDS & Hands on Activity, PODE, Science Process Skills \\
\hline cc) (†) (9) & $\begin{array}{l}\text { This work is licensed under a Creative Commons } \\
\text { Attribution-ShareAlike 4.0 International }\end{array}$ \\
\hline
\end{tabular}

\section{INTRODUCTION}

Science or science learning is learning that learns about the process of natural phenomena and natural phenomena in the surrounding environment with problem solving activities to find new theories and concepts of facts (Adriliyani, Dantes, \& Jayanta, 2020). Competence in learning science or science in SD/MI, namely: knowing various types, natural or artificial environments and their relation to use in everyday life in developing a series of activities called science process skills (Yunianto, 2021). The science learning process in elementary schools is more meaningful if the learning materials are linked in everyday life, so that students can acquire a series of factual scientific knowledge processes and study natural science phenomena around them in order to realize conceptual knowledge and develop students' skills and be able to solve problems with a series of discovery process (Azam \& Rokhimawan, 2020).

The initial observation study in the fourth grade of SDN Gugus Kartini, Mejobo District, Kudus Regency, especially in science learning, the science learning process in the teacher class still dominates or is teacher centered. Science learning rarely applies practical methods so that students are not trained in solving problems, as well as a lack of practical activities. During the learning process students are still passive, less active in discussing, asking questions and expressing opinions. So that the mid-semester assessment learning outcomes in science learning are still low below the KKM, which is 70. The results of the second semester science PTS IV in the Kartini Cluster get an average score of 65.44 .

Based on the average mid-semester assessment (PTS), it still does not meet the KKM criteria. Judging from the low learning outcomes, students are less trained to do thinking skills to solve a problem scientifically. The results of interviews with teachers found that at the time of learning the teacher only focused on conceptual results rather than the process, so that students' scientific skills were not trained and had never been applied. Science learning is said to be effective if students study a problem with a series of process skills activities by conducting practicals/experiments to find concepts. Science process skills are scientific activities used to find a concept or theory to develop an existing concept or negate previous findings (Ilmi, Nazwatul et al., 2016; Emda, Amna., 2017).

The condition of the problem of science learning above, it is necessary to apply an innovative learning activity that can involve students directly through the learning process of active discussion activities, conducting experiments and inquiries. Science learning that is currently developing in elementary schools, in the learning process requires students to be more focused on finding and solving problems (Sudana \& Wesnawa, 2017). In this effort, teachers are more creative and innovative in formulating learning strategies. Innovative learning planning using a learning strategy can affect science process skills. One of the efforts to improve students' science process skills is to apply the Hands On Activity approach in the Predict-Observe-Discuss-Explain (PODE) learning model. The PODE learning model is a series of activities to predict, observe, discuss and explain (Avisya, Miriam, \& Suyidno, 2019).

The PODE learning model is based on constructivist learning theory in the process of forming students' knowledge to be more active in carrying out various active 
activities that can give meaning to what is being studied (Hammond et al., 2020). Constructivist learning theory was developed by Piaget. Constructivist learning emphasizes three important things, namely that first, learning is an active process of constructing knowledge; the second actively forms a link between the knowledge possessed by students and the knowledge being studied; the third interacts with other students (Sulistyowati, 2019). Constructivistic theory in the PODE model, students learn actively to gain an understanding of initial and final knowledge. Student learning activities interact with groups to work together to discuss the results of ideas and convey the results of the ideas discussed (Shah, 2019).

Research (Retnosari \& Widodo., 2018) entitled LKS PODE (Predict-ObserveDiscuss-Explain) To Improve Students' Critical Thinking Skills. The purpose of the study was to describe the implementation of learning, student responses, and improvement of critical thinking skills after using the PODE LKS. The results of the implementation of the learning process using LKS are known to be carried out with good and increasing average results. The average learning process meeting obtained an average score of $77.32 \%$ for the first meeting, $82.68 \%$ for the second and $100 \%$ for the third meeting. Thinking skills test results Critical thinking shows the results of the pretest and posttest calculated with a gain score showing a score of 0.42 in the medium category. The results of Retnosari \& Widodo's research show that there is an increase in critical thinking skills in the PODE LKS.

Irfan, M \& Syahrani. (2018). Reviewing research on the application of the Predict Observe, Discuss, Explain (PODE) Learning Model to Improve Science Process Skills for Class V Elementary School Students at the Inpres Superior BTN Makassar City Government. The purpose of Irfan \& Syahrani's research is to describe the science process skills of fifth grade students by applying the PODE model. The research used was descriptive quantitative. The results showed that science process skills were categorized as good, with an average of 2.82, so it can be concluded that using the PODE model can improve science process skills. The difference between Irfan \& Syahrani's research and that of the researcher is that Irfan \& Syahrani's research focuses on the independent variable, namely the ability of science process skills to fifth grade students, while the researcher refers to the independent variable understanding concepts and science process skills.

The PODE model is implemented with practical activities or Hands On Activity. Hands on Activity is an activity that involves students to be active in digging for information, asking questions, doing activities, finding, collecting data, analyzing and making their own conclusions (Ismi \& Pahriah, 2016). The Hands On Activity activity is designed to involve students' activities in building thinking skills by means of practical activities to design experiments using tools, seek information, collect data, analyze and make conclusions from the results of activities during practical activities (Tu, Liu, \& Wu, 2018). Through Hands On Activity practices, experiences and activities, learning can bring about change in students. Hands On Activity can help students move/work and be scientific as well as communicate knowledge that is optimized with practical activities (Jannah, 2017).

Previous research, Application of Hands on Activity-Based Cooperative Learning Model to Improve Science Process Skills, research from Avisya et al (2019). Aims to describe the improvement of process skills in the Hands on Activity-based Cooperative learning model in class VIII E SMPN 25 Banjarmasin. The research method used is classroom action research (CAR). Analysis in the implementation of the RPP average value of cycle 1 was 85.75 , cycle 2 obtained a value of 95.13 and cycle 3 obtained a value of 98.38 . 
The three cycles are categorized as very good so that the implementation of the lesson plan by applying the Hands on Activity cooperative learning model has an impact on the activity of the learning process. Science process skills in cycle 1, indicators (observing) criteria are good, indicators (concludes and communicating) criteria are sufficient, and indicators (predicts) get very good criteria, while cycles 2 and cycle 3 get good and very good criteria. Increased learning outcomes are shown in cycle 1 (18.75\%), cycle $2(56.25 \%)$ in the incomplete category and cycle $3(87.50 \%)$ in the complete category.

The cooperative learning model based on hands on activity has advantages, namely it can improve students' science process skills by utilizing the learning environment, the learning process is focused on hands on activity, namely in each phase of hands on activity students play an active role during the learning process (Avisya, Nanda et al, 2019). The cooperative learning model is believed to make students work together, help each other, and complement each other, both in studying teaching materials and in doing hands on activities (Ratumanan, 2015). The application of the PODE model with Hands on Activity is implemented in learning activities, so that students are more active, cooperate and play a direct role in practical activities.

Student learning activities in Hands On Activity in the application of the PODE model, the structure of students' initial knowledge is tested with Predict or predicting activities. Observe or observe; students observe by doing practical activities directly, after predicting a phenomenon that students have, collect data on the results of observations which are then analyzed by predicting results. Discuss or discussion; students actively discuss in groups and collect the results of the analysis of predictive and observing activities. Explain or explain; students convey the results of predicting, observing, discussing. Based on the description above, the purpose of this study was to find out "Analysis of the Role of Hands On Activity in the application of PODE in terms of the science process skills of students in elementary schools". The difference in this study is the application of the role of Hands on Activity in the PODE model, while the existing research is only the PODE model.

\section{RESEARCH METHOD}

This research was conducted at SD 1 Gulang and SD 1 Payaman, Mejobo District, Kudus Regency. The design used in this study is a Quasi Experimental Design in the form of Nonequivalent Control Group Design. Design of Nonequivalent Control Group The design of the experimental group and the control group were not chosen randomly (Sugiyono, 2019:120). In the experimental class students were given treatment using Hands on Activity learning with the application of the PODE model, while the control class used the PODE model. Nonequivalent Control Group Design according to Sugiyono (2019: 120) is as follows:

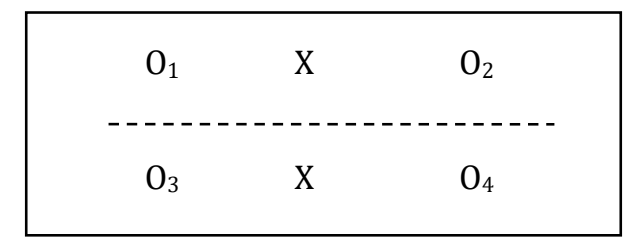

Descriptiom :

Experiment $=$ Experimental group $($ Hands on Activity with the application of the PODE model) 
Control $=$ Control group $($ PODE Model)

$\mathrm{O} 1=$ Pretest experimental group

$\mathrm{O} 2=$ Posttest experimental group

$\mathrm{O} 3=$ Pretest control group

$\mathrm{O} 4=$ Posttest control group

$\mathrm{X}=$ Treatment (treatment)

The population in this study were fourth grade students of SD 1 Gulang and SD 1 Payaman with a total of 60 students. The research sample for the experimental class was students of SD 1 Gulang with a total of 30 students, for the control class, students of SD 1 Payaman, amounting to 30 students. The independent variables in this study were Hands on Activity (X1) and the PODE model (X2), while the dependent variable was science process skills (Y1). The instrument in this study was a science process skill observation sheet. The research instrument was in the form of non-test, to obtain data and analysis results of science process skills. Indicators of science process skills include observing, classifying, conducting experiments, communicating, concluding answers.

Data collection techniques in this study include interviews, documentation and observation of preliminary studies of data collection and observation of data collection by observing the learning process which aims to analyze science process skills on the basic competencies of various forces, including muscle, electric, magnetic, gravity and swipe.

The data analysis technique in this study was simple regression analysis to determine the effect of Hands on Activity (X1), PODE model (X2) on science process skills (Y1). Multiple regression analysis to determine the effect of Hands On Activity (X1) and PODE model (X2) together on science process skills (Y1).

\section{RESULT AND DISCUSSION}

\section{A. Initial data analysis \\ 1. Normality Test}

The normality test of the experimental and control class data was used to determine whether the pretest-posttest results were normally distributed or not.

Table 1 Recapitulation of Normality Test Results for Experimental Class and Control Pretest-Posttest

\begin{tabular}{llllll}
\hline \multirow{3}{*}{ Class } & & \multicolumn{3}{c}{ Kolmogorov-Smirnov $^{\mathrm{a}}$} \\
& & Statistic & $\mathrm{df}$ & & Sig. \\
& PreTest Experiment & .154 & 30 & .068 & \\
& PostTest Experiment & .157 & 30 & .058 & \\
& PreTest Control & .145 & 30 & .107 & \\
& PostTest Control & .152 & 30 & .077 & \\
\hline
\end{tabular}

Based on Table 1 above, it can be seen that the data is normally distributed if the significance value (Sig.) in the Kolmogorov-Smirnov column is more than 0.05 . The significance value of the normality test data above is 0.068 in the experimental class pretest, 0.058 in the experimental class posttest, 0.107 in the control class pretest, and 0.077 in the control class posttest. Because the significance value is above 0.05 , it can be concluded that the data is normally distributed.

1. Homogeneity Test

Homogeneity test is used to determine whether there is a similarity of variance in the experimental class and the control class. The calculation of the homogeneity test uses the Levene test. The calculation results show that the significance value is 0.055 at the significance level $=0.05$. Based on Levene's test calculations, it proves that the 


\section{Fiky Herdianto, Hartono Hartono, Ali Sunarso}

experimental and control classes come from the same or homogeneous variance.

2. Linearity Test

The linearity test is used to determine whether there is a linear relationship between the independent and dependent variables.

Table 2 Results of Hands on Activity Linearity Test and PODE model on science process skills

\begin{tabular}{cll}
\hline \multicolumn{1}{c}{ Variable } & F Value & Sig. \\
Hands on Activity - Science process skills & 2,578 & 0,095 \\
PODE Model - Science process skills & 1,422 & 0,260 \\
\hline
\end{tabular}

Based on Table 2 shows that the value of sig. The first deviation from linearity is $0.095>0.05$, it can be concluded that there is a linear relationship between science process skills and Hands on Activity. While the value of sig. the second deviation from linearity is $0.260>0.05$, it can be concluded that there is a linear relationship between science process skills and the PODE model.

1. Multicollinearity Test

To detect the presence or absence of multicollinearity can be seen from the amount of Variance Inflation Factor (VIF) and Tolerance. The guideline for a regression model that is free of multicollinearity is to have a tolerance number close to 1 . The VIF limit is 10 , if the VIF value is below 10, then there is no multicollinearity symptom.

Table 3 Multicollinearity Test Results

\begin{tabular}{lcc}
\hline Model & \multicolumn{2}{c}{ Collinearity Statistics } \\
& Tolerance & VIF \\
PODE & .177 & 5.656 \\
Hans On Activity & .177 & 5.656 \\
\hline
\end{tabular}

Based on Table 3 above, the coefficient of the independent variable shows the VIF number is less than $10>5.656$. The tolerance value is more than $0.1<0.177$, it can be concluded that the laying regression model is used.

1. Heteroscedasticity Test

To determine heteroscedasticity can use the Glejser test. The basis for decision making in this test is if the significance value $=0.05$, it can be concluded that there is no heteroscedasticity problem, but on the contrary if the significance value is $<0.05$, it can be concluded that there is a heteroscedasticity problem. The results of the heteroscedasticity test obtained are as follows:

Table 4 Heteroscedasticity Test Results

\begin{tabular}{|c|c|c|c|c|c|c|c|c|}
\hline & \multicolumn{3}{|c|}{ Unstandardized } & \multicolumn{4}{|l|}{$\begin{array}{l}\text { Standardized } \\
\text { Coefficients }\end{array}$} \\
\hline & & & $\mathrm{B}$ & Std. Error & Beta & & & Sig. \\
\hline \multirow[t]{3}{*}{1} & (Constant) & & 11.029 & 7.602 & & 1.451 & .158 & \\
\hline & $\begin{array}{l}\text { Hands } \\
\text { Activity }\end{array}$ & On & -.188 & .202 & -.415 & -.929 & .361 & \\
\hline & PODE & & .106 & .198 & .239 & .535 & .597 & \\
\hline
\end{tabular}

In the calculation results in Table 4 above, it is known that the significance value of the Hans On Activity variable and the PODE Model variable is more than 0.05 (respectively 0.361 and 0.597 ). Based on this, it can be concluded that there is no heteroscedasticity between independent variables in the regression model. 
Data on the results of science process skills were obtained from the beginning of learning and at the end. Early and late learning scores are shown in Table 5 below.

Table 5 Scores of early and late learning of science process skills

\begin{tabular}{lcc}
\hline Data & Class & Average \% \\
& & \\
Early learning & E & 58,00 \\
& K & 56,00 \\
Final learning & E & 88,00 \\
& K & 69,33
\end{tabular}

Table 5 can be seen that the average science process skills is 58.00 while the control class is 56.00. The score increases after learning is done, the average score achieved by the experimental class students is 88.00 while the control class is 69.33 which gets a higher score is the class that uses PODE and Hands on Activity modes. Furthermore, to find out the difference between the pretest and posttest scores, the gain test was continued. The gain test of science process skills scores can be seen in Table 6 .

Table 6 Gain Score Test Results Science Process Skills

\begin{tabular}{|c|c|c|c|c|}
\hline \multirow{2}{*}{ Group } & \multicolumn{2}{|c|}{ Average } & \multirow{2}{*}{ N-Gain } & \multirow{2}{*}{ Description } \\
\hline & Pre-test & Post Test & & \\
\hline Experiment Class & 58,00 & 88,00 & 0,70 & High \\
\hline Control Class & 56,00 & 69,33 & 0,28 & Low \\
\hline
\end{tabular}

Table 6 shows that the N-gain of the KPS in the experimental class shows 0.70 and the $\mathrm{N}$-gain in the control class shows 0.28 . The $\mathrm{N}$-Gain classification is as follows: $\mathrm{g}<$ $0.30=$ low, $030<\mathrm{g}>0.70=$ moderate, $\mathrm{g}>0.70=$ high. The results of the experimental class $\mathrm{N}$-gain are in the medium category, while the control class is in the low category. The gain test results for the experimental class are higher than the control class, so it can be concluded that the KPS in the experimental class is better than the control class. Furthermore, to prove the hypothesis, it is followed by a paired t-test can be seen in Table 7.

Table 7 Paired sample t test results

Paired Samples Test

$$
\begin{aligned}
& \text { 95\% Confidence } \\
& \text { Interval of the } \\
& \text { Difference }
\end{aligned}
$$

\begin{tabular}{|c|c|c|c|c|c|c|c|c|c|}
\hline & & Mean & $\begin{array}{l}\text { Std. } \\
\text { Deviati } \\
\text { on }\end{array}$ & $\begin{array}{l}\text { Std. } \\
\text { Eror } \\
\text { Mean }\end{array}$ & Lower & Upper & t & $\mathrm{df}$ & $\begin{array}{l}\text { Sig } \\
\text { (2- } \\
\text { tail } \\
\text { ed }\end{array}$ \\
\hline $\begin{array}{l}\text { Experi } \\
\text { ment }\end{array}$ & $\begin{array}{l}\text { Pretest } \\
\text { Postest }\end{array}$ & $\begin{array}{l}- \\
30.000\end{array}$ & 12.177 & 2.223 & $\begin{array}{l}- \\
34.547\end{array}$ & -25.453 & $\begin{array}{l}- \\
13.4 \\
94\end{array}$ & 29 & $\begin{array}{l}.00 \\
0\end{array}$ \\
\hline Control & $\begin{array}{l}\text { Pretest } \\
\text { Posttes } \\
\mathrm{t}\end{array}$ & $\overline{-}$ & 11.090 & 2.025 & $\overline{-}-\overline{17.474}$ & -9.192 & $\begin{array}{l}- \\
6.58 \\
5\end{array}$ & 29 & $\begin{array}{l}.00 \\
0\end{array}$ \\
\hline
\end{tabular}

Based on the results of the pair 1 experimental group in Table 7 above, the value of tcount $=13,494>$ ttable $=2,045$ and the value of Sig. (2-tailed) of $0.000<0.05$, it can be 
concluded that there is a difference in the average KPS for the experimental class pre-test with the post-test experimental class using the PODE and Hands On Activity models. While the results of pair 2 obtained the value of tcount $=6.585>$ ttable $=2.045$ and the value of Sig. (2-tailed) of $0.000>0.05$, it can be concluded that there is a difference in the average KPS for the control class pre-test and post-test control class students' concept understanding for the experimental class pre-test with the experimental class post-test using PODE model without Hands On Activity.

A. Simple and multiple regression analysis

The results of the regression equation for the PODE model variable on the control class KPS can be seen in Table 8 below.

Table 8 Simple Regression Test Results of the PODE Model on the Control Class KPS

\begin{tabular}{|c|c|c|c|c|c|}
\hline \multirow{3}{*}{$\begin{array}{l}\text { Model } \\
\text { (Constant) } \\
\text { PODE (K) }\end{array}$} & \multicolumn{2}{|c|}{$\begin{array}{l}\text { Unstandardized } \\
\text { Coefficients }\end{array}$} & \multicolumn{3}{|l|}{$\begin{array}{l}\text { Standardized } \\
\text { Coefficients }\end{array}$} \\
\hline & $\begin{array}{ll}B & \\
& 13.826\end{array}$ & $\begin{array}{c}\text { Std. Error } \\
11.087\end{array}$ & Beta & ${ }^{t}{ }_{1.247}$ & $\begin{array}{l}\text { Sig. } \\
\quad .223\end{array}$ \\
\hline & .735 & .137 & .712 & 5.369 & .000 \\
\hline
\end{tabular}

Based on Table 8 above, it is known that the value of Sig. for the effect of the PODE model on KPS of $0.000<0.05$ and the value of tcount $5.369>$ ttable 2.045, so it can be concluded that there is an effect of the PODE model on PPP. From the table above, the regression equation $\mathrm{Y} 2=(13,826)+0.735 \mathrm{X} 2$ is also formed. From this equation, it can be interpreted that the effect of the PODE (X2) model on PPP (Y2) is positive. This can be seen from the regression coefficient (X2) of 0.735 which is positive, indicating that the effect of the PODE model on PPP is positive. This condition implies that the more effective the implementation of the PODE model, the better the PPP. The magnitude of the influence of the PODE model on KPS the value of the coefficient of determination (R2) of the PODE model variable on KPS is 0.507. This shows that the magnitude of the PODE model on the concept understanding of the control class students is $50.7 \%$. The results of the regression equation for the PODE model variable on the experimental class KPS can be seen in Table 9 below.

Table 9 Simple Regression Test Results of the PODE Model on the Experimental Class KPS

\begin{tabular}{llllllll}
\hline & \multicolumn{9}{c}{$\begin{array}{l}\text { Unstandardized } \\
\text { Coefficients }\end{array}$} & \multicolumn{3}{c}{$\begin{array}{l}\text { Standardized } \\
\text { Coefficients }\end{array}$} \\
Model & \multicolumn{9}{c}{ B } & Std. Error & Beta & \multicolumn{2}{c}{$t$ Sig. } \\
& & (Constant) & -13.116 & 10.636 & & -1.233 & .228 \\
& PODE (E) & 1.155 & .121 & .874 & 9.529 & .000 \\
\hline
\end{tabular}

Based on Table 9 above, it is known that the value of Sig. for the effect of the PODE model on the experimental class KPS of $0.000<0.05$ and the tcount $9.529>$ ttable 2.045 , so it can be concluded that there is an effect of the PODE model on the KPS. From Table 4.18 above, the regression equation Y2 $=(-13,116)+1,155 \mathrm{X} 2$ is also formed. From this equation, it can be interpreted that the effect of the PODE (X2) model on PPP (Y2) is positive. This can be seen from the regression coefficient (X2) of 1.155 which is positive. 
This condition implies that the more effective the implementation of the PODE model, the better the PPP. The magnitude of the effect of the PODE model on science process skills, the coefficient of determination (R2) of the PODE model variable on KPS understanding is 0.764 . This shows the effect of the magnitude of the PODE model on the experimental class KPS of $76.4 \%$. When compared between the experimental class and the control class, the effect of the PODE model on KPS in the experimental class is higher with a ratio of $76.4 \%$ compared to $50.7 \%$.

The results of the regression equation for the Hands on Activity variable on the experimental class KPS can be seen in Table 10 below.

Table 10 Simple Regression Test Results Hands on Activity Against KPS Experiment Class

\begin{tabular}{|c|c|c|c|c|c|}
\hline \multirow{3}{*}{$\begin{array}{l}\text { Model } \\
\quad \text { (Constant) } \\
\quad \text { Hands on (E) }\end{array}$} & \multicolumn{2}{|c|}{$\begin{array}{l}\text { Unstandardized } \\
\text { Coefficients }\end{array}$} & \multicolumn{3}{|l|}{$\begin{array}{l}\text { Standardized } \\
\text { Coefficients }\end{array}$} \\
\hline & $\begin{array}{l}B \\
.561\end{array}$ & $\begin{array}{l}\text { Std. Error } \\
13.198\end{array}$ & Beta & $\begin{array}{l}t \\
.043\end{array}$ & $\begin{array}{l}\text { Sig. } \\
.966\end{array}$ \\
\hline & .988 & .149 & .782 & 6.642 & .000 \\
\hline
\end{tabular}

Based on Table 10, it is known that the value of Sig. for the effect of Hands on Activity on the experimental class KPS of $0.000<0.05$ and the tcount $6.642>$ ttable 2.045, so it can be concluded that there is an effect of Hands on Activity on the KPS. From Table 4.22 above, the regression equation $\mathrm{Y} 2=(-13,116)+1,155 \mathrm{X} 1$ is also formed. From this equation, it can be interpreted that the effect of Hands on Activity (X2) on KPS (Y2) is positive. This can be seen from the regression coefficient (X1) of 0.988 which is positive, indicating that the effect of Hands on Activity on the experimental class KPS is positive. This condition implies that the more effective the implementation of Hands on Activity, the better the PPP. The magnitude of the influence of Hands on Activity on the KPS of the experimental class, the value of the coefficient of determination (R2) of the Hands on Activity variable on the understanding of KPS is 0.612 . This shows the effect of the magnitude of Hands on Activity on the experimental class KPS of $61.2 \%$.

The next statistical analysis is aimed at knowing the magnitude of the influence of the independent variable Hands on Activity (X1) and the PODE model (X2) on the dependent variable understanding of the concept (Y1) together in the experimental class. Statistical analysis to determine the effect of the independent variable Hands on Activity (X1) and the PODE model (X2) on the dependent variable KPS (Y2) together in the experimental class. The analysis used is through multiple regression equations. Based on calculations using the SPSS program, the regression contained in Table 11 is obtained as follows.

Table 11 Results of Hands on Activity Multiple Linear Regression and PODE Model on KPS

\begin{tabular}{|c|c|c|c|c|}
\hline \multirow[b]{2}{*}{ Model } & \multicolumn{2}{|c|}{$\begin{array}{l}\text { Unstandardized } \\
\text { Coefficients }\end{array}$} & \multirow{2}{*}{$\begin{array}{c}\text { Standardized } \\
\text { Coefficients } \\
\text { Beta }\end{array}$} & \multirow[t]{2}{*}{ Sig. } \\
\hline & $B$ & Std. Error & & \\
\hline (Constant) & -13.563 & 10.990 & & -1.234 .228 \\
\hline PODE (X2) & 1.101 & .263 & .833 & 4.192 .000 \\
\hline Hands On Activity (X1) & .058 & .251 & .046 & $.233 \quad .818$ \\
\hline
\end{tabular}


Based on the results of the analysis in Table 11, it can be seen that the regression equation formed is $\mathrm{Y} 2=-13,563+1,101 \mathrm{X} 1+0,58 \mathrm{X} 2$. In addition, it was also found that the most influential independent variable was the PODE model variable with a coefficient of 1.101. While the variable that has a lower effect is the Hands on Activity variable with a coefficient value of 0.058 .

From this equation, it can be seen that all the independent variables Hands on Activity (X1) and the PODE model (X2) have a positive effect on KPS (Y2). This means that better use of Hands on Activity and the PODE model results in an increase in KPS.

The coefficient of determination (R2) essentially measures how far the model's ability to explain the dependent variable is. The value of the coefficient of independent determination shows the more dominant influence on the dependent variable. The value of the coefficient of determination is 0 and 1 . The greater $\mathrm{R} 2$ of an independent variable, the more dominant the influence on the dependent variable is. The results of the calculation of the coefficient of determination of the independent variable Hands on Activity (X1) and the PODE model (X2) on KPS (Y2), the effect of the independent variable on the dependent variable is indicated by the coefficient of determination (R2) of 0.765 or $76.5 \%$. This means that the Hands on Activity learning variable and the PODE model are able to explain the variation of KPS by $76.5 \%$ while the remaining $23.5 \%$ is explained by variables outside of this study. The results of the research together with the Hands on Activity variable and the PODE model on PPP can be seen in table 12 below.

Table 12 Test Results of Simultaneous Effects of Hands on Activity Variables and the PODE Model on KPS

\begin{tabular}{rclccr}
\hline Model & Sum of Squares & Df & Mean Square & F & Sig. \\
1 Regression & 1476.060 & 2 & 738.030 & 43.897 & $.000^{\mathrm{b}}$ \\
Residual & 453.940 & 27 & 16.813 & & \\
Total & 1930.000 & 29 & & & \\
\hline
\end{tabular}

Based on the output of Table 12, it is known that the significance value (Sig.) for the effect of Simultaneous Hands on Activity learning and the PODE model on KPS is $0.000<0.05$ and the value of Fcount $43.897>$ Ftable 3.33, so it can be concluded that there is an effect of Hands on Activity (X1) and PODE model (X2) simultaneously on KPS (Y2).

\section{DISCUSSION}

In the control class of the PODE model on science process skills, the results of the analysis show the influence of the PODE model on science process skills. The results of the regression equation $\mathrm{Y} 2=(13,826)+0.735 \mathrm{X} 2$, which means that the effect of the PODE (X2) model on KPS (Y2) is positive. This can be seen from the regression coefficient of 0.735 which is positive. The result of the calculation of the coefficient of determination (R2) of the PODE model on science process skills is $50.7 \%$. Based on the results of the analysis of the findings of this study, the application of the PODE model to science process skills in the control class

Based on research (Zulaeha, et al. 2014) on the effect of the POE model on science process skills, it explains that there is an effect of science process skills on classes that use the POE learning model with classes that use conventional learning. In line with research (Gultom. 2018) explaining that science process skills using the POE model get significant results, this is because the POE model activities make students develop their cognitive structures.

The results of the analysis of the experimental class science process skills 
indicators on the indicators of observing, classifying, conducting experiments, communicating and concluding answers obtained very good criteria with a total percentage of $86.67 \%, 81.67 \%, 90.83 \%, 90.83 \%$, respectively. , 90.00\%. Based on the results of the percentage of science process skills in the control class and the experimental class, there was an increase in each indicator. Based on simple regression analysis, there is an effect of the PODE model on science process skills, the results of the Sig value. of $0.000<0.05$ and the value of tcount $9.529>$ ttable 2.045 . The results of the regression equation $\mathrm{Y} 2=(-13.116)+1.155 \mathrm{X} 2$, the results of the equation mean that the effect of the PODE (X2) model on KPS (Y2) is positive. The magnitude of the coefficient of determination of the influence of the PODE model on the science process skills of the experimental class is (R2) of 0.764 or $76.4 \%$. The conclusion between the experimental class and the control class is that the effect of the PODE model on science process skills is higher with a ratio of $76.4 \%$ vs. $50.7 \%$.

The results of research (Irfan \& Syahrani, 2018) on the PODE model to improve science process skills explain that the indicators of observation, prediction, conducting experiments are in the good category, while drawing conclusions and reporting are in the sufficient category. Research (Wlandari, et al. 2014) has a positive influence on the application of the PODE strategy to science process skills.

The results of the simple regression analysis of Hands on Activity on the science process skills of the experimental class, it is known that the value of Sig. of $0.000<0.05$ and the value of tcount $6.642>$ ttable 2.045. The conclusion from the results of the value of Sig. is that there is an effect of Hands on Activity on science process skills. The results of the regression equation $\mathrm{Y} 2=(0.561)+0.988 \mathrm{X} 1$, based on the results of the equation, it can be interpreted that the effect of Hands on Activity on science process skills is positive. The regression coefficient of $\mathrm{X} 1$ is 0.988 which is positive. The value of the coefficient of determination (R2) for the Hands on Activity variable on science process skills is 0.162 or $61.2 \%$. Research (Avisya, et al. 2019) the application of the Hands on Activity-based cooperative model to science process skills has increased, student learning outcomes from cycle I (18.75\%), cycle II $(56.25 \%)$ with incomplete categories to (87 ,50\&) with a complete category in cycle III. In line with research with research (Asmawati, et al. 2017) with the title of the research the effect of a Hands on Activitybased contextual approach on science process skills, the results of the study showed that the posttest average for the experimental class was 47.59 and the control class was 55.8. The results of the experimental class science process skills score got an average result of 77.33 in the high category.

The results of multiple linear analysis of the effect of the Hands on Activity (X1) variable in the PODE model (X2) on science process skills (Y2), it is known that the resulting equation is $\mathrm{Y} 2=-13,563+1,101 \mathrm{X} 1+0,58 \mathrm{X} 2$. The independent variable that has an effect is the PODE model with a coefficient of 1.101 while the variable that has a lower effect is Hands on Activity with a coefficient value of 0.058 . The equation can be concluded that Hands on Activity and the PODE model have a positive effect on science process skills. Based on the calculation of the coefficient of determination (R2) of 0.765 or $76.5 \%$, which means that the Hands on Activity learning in the PODE model is able to explain variations in science process skills by $76.5 \%$ for the remaining $23.5 \%$ explained by variables outside this study. Value of Sig. Simultaneous effect test is $0.000<0.05$ and Fcount $43.897>$ Ftable 3.33, and it can be concluded that there is an effect of Hands on Activity (X1) and PODE model (X2) simultaneously on science process skills.

The findings in the field show that the expert class student experiments using Hands on Activity science learning in the application of PODE, students are more active and independent in direct activity experimental activities, students are very enthusiastic 
when observing experiments, in discussing students work together to express opinions in solving problems, the role of Hands on Activity in the learning process Activities Practicum on Hands on Activity in the application of the PODE model is more focused by designing experiments, seeking information, collecting data and analyzing the data obtained. While learning science in the control class using the PODE model, in the learning process students must still be directed by the teacher. In the experimental activities only a few students were active, in terms of observing, discussing and explaining.

\section{CONCLUSION}

Based on the results of research and discussion, it can be concluded that, 1) There are differences in the results of science process skills between learning Hands on Activity with the application of the PODE model and students using the PODE model only. 2) There are differences in science process skills in the experimental class in the application of Hands on Activity and the PODE model has a positive effect of $76.4 \%$ and $61.2 \%$, while the control class using the PODE model has an effect of 50.7\%. 3) The results of the multiple linear test of science process skills obtained results of $76.5 \%$, the results of the Sig. Simultaneous effect test is $0.000<0.05$ and Fcount $43.897>$ Ftable 3.33, and it can be concluded that there is an effect of Hands on Activity (X1) and PODE model (X2) simultaneously on science process skills.

The results of research on the analysis of the role of Hands On Activity in the application of the PODE model in terms of science process skills in elementary schools can be concluded that the role of Hands On Activity with the PODE model can improve science process skills of elementary school students. The results of the research can theoretically be used as study material and references in similar research using the role of Hands On Activity and/or the PODE learning model. Practically, the results of this study can be used as consideration for teachers or other researchers in developing a variety of learning activities in the classroom in an effort to improve students' science process skills.

\section{REFERENCES}

Adriliyani, Putu Ayu, Dantes, Nyoman, \& Jayanta, I. Nyoman Laba. (2020). Pembelajaran IPA Dengan Model Make A Match Berbasis Lingkungan Meningkatkan Hasil Belajar Siswa. MIMBAR PGSD Undiksha, 8(2), 181-191.

Avisya, Nanda, Miriam, Sarah, \& Suyidno, Suyidno. (2019). Penerapan Model Pembelajaran Kooperatif Berbasis Hands on Activity untuk Meningkatkan Keterampilan Proses Sains. Jurnal Ilmiah Pendidikan Fisika, 3(3), 94. https://doi.org/10.20527/jipf.v3i3.1036

Azam, Ismuhul Fadhil, \& Rokhimawan, Moh. Agung. (2020). Analisis Materi Ipa Kelas Iv Tema Indahnya Kebersamaan Dengan Hots. JURNAL ILMIAH DIDAKTIKA: Media Ilmiah Pendidikan Dan Pengajaran, 21(1), 100-110. https://doi.org/10.22373/jid.v21i1.5970

Hammond, Darling, Flook, Linda, Cook-Harvey, Lisa, Barron, Channa, Osher, Brigid, \& David. (2020). Implications for educational practice of the science of learning and development. Applied Developmental Science, 24(2), 97-140. https://doi.org/10.1080/10888691.2018.1537791

Jannah, Novaria Lailatul. (2017). Penerapan Model Pembelajaran POE ( Predict, Observe , Explain ) Untuk Meningkatkan Keterampilan Pemecahan Masalah Pada Mata Pelajaran IPA di Sekolah Dasar. Jurnal Program Studi PGMI, 4(1), 133-150. 
Shah, Dr. Rajendra Kumar. (2019). Effective Constructivist Teaching Learning in the Classroom. 7(1), 1-13.

Sulistyowati, Titis. (2019). BOTTOM-UP AND TOP-DOWN LISTENING PROCESSES WITHIN COGNITIVE CONSTRUCTIVIST LEARNING THEORY. PROMINENT Journal, 2(1), 92-100.

Tu, Jui Che, Liu, Li Xia, \& Wu, Kuan Yi. (2018). Study on the Learning Effectiveness of Stanford Design Thinking in Integrated Design Education. Sustainability (Switzerland), 10(8), 1-21. https://doi.org/10.3390/su10082649

Yunianto, Teguh. (2021). ANALISIS KESESUAIAN MATERI IPA DALAM BUKU SISWA KELAS IV SEMESTER 1 SD / MI DENGAN KURIKULUM 2013 ANALYSIS OF THE COMPATIBILITY OF SCIENCE MATERIALS IN THE FIRST SEMESTER GRADE 4 STUDENT BOOK SD / MI IN CURRICULUM 2013 PENDAHULUAN Abad ke-21 yang dikaitka. 8(1), 1-17. 